УДК 347

DOI https://doi.org/10.51989/NUL.2021.5.19

\title{
СТЯГНЕННЯ ПРОЦЕНТІВ ЗА КОРИСТУВАННЯ ЧУЖИМИ ГРОШОВИМИ КОШТАМИ ЯК СПЕЦІАЛЬНИЙ СПОСІБ ЗАХИСТУ СУБ'ЄКТИВНИХ ЦИВІЛЬНИХ ПРАВ У ДОГОВІРНИХ ЗОБОВ'ЯЗАННЯХ
}

\author{
Мартинюк Юрій Володимирович, \\ аспірант юридичного факультету \\ Західноукраїнського національного університету, \\ адвокат
}

Статтю присвячено аналізу такого різновиду спеціальних способів захисту цивільних прав у договірних зобов'язаннях, як стягнення процентів за користування чужими грошовими коштами. Висловлено авторське спостереження, що у сфері вивчення природи спеціальних способів захисту договірних прав здебільшого дослідники приділяли увагу саме загальним способам захисту, мимоволі залишали поза увагою систематизацію спеціальних. Установлено, що чимало способів захисту договірних прав, закріплених у спеціальних нормах цивільного законодавства, за своєю сутністю також є деталізацією й адаптацією до специфіки договірних правовідносин загальних способів захисту цивільних прав, що знаходять своє закріплення в положеннях частини 2 статті 16 Цивільного кодексу України. Обгрунтовано притаманність стягненню процентів за користування чужими грошовими коштами подвійної правової природи. У найбільш загальних рисах можливість стягнення процентів за користування чужими грошовими коштами закріплена у статті 536 Цивільного кодексу України, яка включає у свій зміст і зобов'язання щодо їх сплати за належного виконання учасниками договірних правовідносин взятих на себе зобов'язань (договір позики, кредитний договір, договір банківського вкладу, договір банківського рахунка), і зобов'язання, які виникають у божників унаслідок невиконання чи неналежного виконання своїх обов'язків, відповідне порушення договірних прав їхніх контрагентів (договір купівлі-продажу, договір ренти). у першому випадку сплата процентів за користування чужими грошовими коштами за своєю сутністю є грошовим зобов'язанням, має характер звичайної договірної умови і наявна в кожному правовідношенні, опосередковуваному вказаними договірними конструкціями. Натомість у другому випадку сплата процентів за користування чужими грошовими коштами $\epsilon$ забезпеченим законом правовим прийомом, застосовуваним кредитором унаслідок порушення (прострочення) боржником договірного грошового зобов'язання в рамках реалізації захисту своїх порушених суб'єктивних прав, що випливають із договірних правовідносин, та відповідно виконує компенсаційно-захисну функцію.

Ключові слова: захист суб'єктивних цивільних прав, договірні зобов'язання, спеціальний спосіб захисту, сплата процентів за користування чужими грошовими коштами, невиконання, неналежне виконання.

\section{Martyniuk Yurii. Collection of interest for the use of other people's money as a special way to protect subjective civil rights in contractual obligations}

The article is devoted to the analysis of such a variety of special ways to protect civil rights in contractual obligations as the collection of interest for the use of other people's money. The author's observation is expressed that in the field of studying the nature of special methods of protection of contractual rights, researchers mostly paid attention to general methods of protection, involuntarily ignoring the systematization of special ones. It is established that many ways of protection of contractual rights enshrined in special rules of civil law, in essence, are also detailing and adaptation to the specifics of contractual relations of general methods of protection of civil rights, which are enshrined in the provisions of Part 2 of Art. 16 of the Civil Code of Ukraine. The dual legal nature of collecting the interest for the use of other people's money is substantiated. In the most general terms, the possibility of collecting interest for the use of other people's money is enshrined in Art. 536 of the Civil Code of Ukraine, which includes in its content and obligations to pay them in the proper performance of the parties to the contractual obligations (loan agreement, bank deposit agreement, bank account agreement), and obligations that arise from the debtors as a result of non-performance or improper performance of their 
duties and, accordingly, violation of the contractual rights of their counterparties (contract of sale, rental agreement). In the first case, the payment of interest for the use of other people's money is essentially a monetary obligation, has the character of a normal contractual condition and is present in every legal relationship mediated by these contractual constructions. Instead, in the second case, the payment of interest for the use of other people's money is a legally prescribed method used by the creditor as a result of breach (delay) by the debtor of the contractual monetary obligation in the framework of the protection of their violated subjective rights arising from the contractual relationship, and accordingly performs a compensatory and protective function. It is in this, in our opinion, the dual legal nature of the category of payment of interest for the use of other people's money enshrined in Art. 536 of the Civil Code of Ukraine finds its manifestation.

Key words: protection of subjective civil rights, contractual obligations, special method of protection, payment of interest for use of other people's money, non-performance, improper performance.

Спеціальні способи захисту цивільних прав у договірних зобов'язаннях, виділення яких $\epsilon$ результатом проведення класифікації способів захисту за критерієм джерела правового закріплення, становлять ті правові прийоми, можливість застосування яких забезпечується нормами спеціального законодавства, що врегульовують відносини у сфері укладення різноманітних договірних конструкцій, або ж положеннями самих цивільно-правових договорів.

Аналіз наукових джерел у сфері вивчення природи спеціальних способів захисту договірних прав свідчить про те, що здебільшого дослідники у своїх роботах приділяли увагу саме загальним способам захисту, мимоволі залишали поза увагою систематизацію спеціальних. Водночас, як слушно стверджує О.О. Кот, практично щодо кожного пойменованого договору норми цивільного законодавства встановлюють якісь особливі способи захисту й умови їх застосування. У непойменованих договорах сторони зазвичай намагаються самостійно передбачати великий спектр правових можливостей захисту своїх прав від порушення їх іншою стороною зобов'язання, усвідомлюють, що застосування передбачених у законі способів може виявитися проблемним із різних причин [1].

I.B. Болокан, досліджуючи питання зобов'язально-правових і спеціальних засобів захисту права власності в підприємницькій діяльності, пропонує ввести в науковий обіг поняття договірних зобов'язально-правових засобів захисту, які можна визначити як конкретні, передбачені законом або договором вимоги, що можуть бути висунуті суб'єктами підприємницької діяльності до контрагентів у разі порушення умов укладеного договору [2, с. 5]. На її думку, у договірних зобов'язаннях кредитор може захистити свої права шляхом: а) примусу боржника виконати обов'язок у натурі, наприклад, передати кредиторові майно у власність; б) розірвання договору; в) застосування заходів відповідальності, передбачених договором. Необхідність або можливість застосування договірних зобов'язальноправових засобів захисту виникає в разі порушення контрагентом умов укладеного ним договору [3].

у результаті проведеного аналізу запропонованих дослідницею переліків способів захисту прав у договірних зобов'язаннях зазначимо, що вони $є$ дещо умовними, не характеризуються значною системністю і, на наш погляд, виконують здебільшого інформативну функцію щодо ознайомлення з найбільш часто застосовуваними способами захисту, які використовують учасники договірних правовідносин на практиці. Окрім того, зазначимо, що практично кожен із наведених способів має загальний характер і відображений у положеннях ч. 2 ст. 16 Цивільного кодексу (далі - )ЦК України: примусове виконання обов'язку в натурі закріплене в п. 5 цієї статті; припинення (розірвання) договору $\epsilon$ за своєю сутністю способом захисту, передбаченим п. 7 - припиненням правовідношення, а заходи відповідальності, зокрема, відшкодування збитків і моральної шкоди, вміщені у пп. 8-9 ч. 2 ст. 16 ЦК України.

Окрім того, чимало способів захисту договірних прав, закріплених у спеціаль- 
них нормах цивільного законодавства, за своєю сутністю також $є$ деталізацією й адаптацією до специфіки договірних правовідносин загальних способів захисту цивільних прав, що знаходять своє закріплення в положеннях ч. 2 ст. 16 ЦК України.

Розпочинаючи аналіз спеціальних способів захисту суб'єктивних прав у договірних зобов'язаннях, насамперед зазначимо, що в більшості вони закріплені спеціальними нормами цивільного законодавства, які зумовлені специфікою тієї чи іншої договірної конструкції, застосовуються винятково у сфері захисту договірних прав та розкривають унікальність і особливість цього цивільно-правового інституту в договірних зобов'язаннях.

Одним зі спеціальних способів захисту цивільних прав, що виникають із договірних зобов'язань, $\epsilon$ стягнення процентів за користування чужими грошовими коштами. Хоча одразу ж зазначимо, що вказана категорія характеризується подвійною правовою природою.

Загалом юридичним підґрунтям для можливості стягнення процентів за користування чужими грошовими коштами $є$ положення ст. 536 ЦК України, яка визначає, що за користування чужими грошовими коштами боржник зобов'язаний сплачувати проценти, якщо інше не встановлено договором між фізичними особами. Розмір процентів за користування чужими грошовими коштами встановлюється договором, законом або іншим актом цивільного законодавства.

Окрім того, чимало зобов'язань щодо сплати процентів за користування грошовими коштами закріплено у спеціальних положеннях ЦК України, присвячених правовому регулюванню відносин, що опосередковуються різноманітними договірними конструкціями. Так, згідно зі ст. 692 ЦК України покупець за договором купівлі-продажу зобов'язаний оплатити товар після його прийняття або прийняття товаророзпорядчих документів на нього, якщо договором або актами цивільного законодавства не встановлений інший строк оплати товару. У разі прострочення оплати товару продавець має право вимагати оплати товару та сплати процентів за користування чужими гро- шовими коштами. Натомість ст. 693 ЦК України встановлює вже обов'язок продавця щодо сплати ним процентів за користування чужими коштами в разі попередньої оплати товару та невчасного передання ним товару покупцю. Так, на суму попередньої оплати нараховуються проценти відповідно до ст. 536 ЦК України від дня, коли товар мав бути переданий, до дня фактичного передання товару покупцеві або повернення йому суми попередньої оплати. Договором може бути встановлений обов'язок продавця сплачувати проценти на суму попередньої оплати від дня одержання цієї суми від покупця.

Згідно зі ст. 694 ЦК України, яка визначає особливості продажу товару у кредит, якщо покупець прострочив оплату товару, на прострочену суму нараховуються проценти від дня, коли товар мав бути оплачений, до дня його фактичної оплати. Окрім того, договором купівлі-продажу може бути передбачений обов'язок покупця сплачувати проценти на суму, що відповідає ціні товару, проданого у кредит, починаючи від дня передання товару продавцем.

Можливість звернення кредитора з вимогою про сплату боржником процентів за користування чужими грошовими коштами передбачена й у межах правовідносин із договору ренти. Так, згідно зі ст. 736 ЦК України за прострочення виплати ренти платник ренти сплачує одержувачеві ренти проценти.

Натомість за ст. 1048 ЦК України в договорі позики позикодавець має право на одержання від позичальника процентів від суми позики, якщо інше не встановлено договором або законом. Якщо договором не встановлений розмір процентів, їхній розмір визначається на рівні облікової ставки Національного банку України. У разі відсутності іншої домовленості сторін проценти виплачуються щомісяця до дня повернення позики.

Окрім того, згідно зі ст. 1061 ЦК України банк як сторона договору банківського вкладу виплачує вкладникові проценти на суму вкладу в розмірі, встановленому договором банківського вкладу. Якщо договором не встановлений розмір процентів, банк зобов'язаний виплачувати 
проценти в розмірі облікової ставки Національного банку України.

Зазначимо також і закріплений у ст. 1070 ЦК України обов'язок банку за договором банківського рахунку щодо сплати процентів за користування грошовими коштами, які зберігаються на рахунку клієнта. Проценти сплачуються банком у розмірі, встановленому договором, а якщо відповідні умови не встановлені договором, - у розмірі, що звичайно сплачується банком за вкладом на вимогу.

3 аналізу вказаних вище норм ЦК України робимо очевидний висновок про подвійну природу цивільно-правової категорії сплати процентів за користування чужими грошовими коштами, яка проявляється в тому, що, з одного боку, у договірних конструкціях позики, кредиту, банківського вкладу, банківського рахунку обов'язок щодо сплати боржником процентів за користування чужими грошовими коштами не має характеру відповідальності, а навпаки, $\epsilon$ законним грошовим зобов'язанням, зумовленим сторонами договору добровільно. У цьому контексті доцільно навести думку Є.О. Суханова, який зазначає, що головна особливість грошового зобов'язання в тому, що «воно має своїм предметом гроші, які в нормальному цивільному обороті завжди дають певний «приріст» незалежно від зусиль їх власника (бо зазвичай він передає їх до банку або іншої кредитної організації й отримує середній річний відсоток, що становить ніби «природний приріст»). Той, у кого знаходяться грошові кошти, що підлягають передачі іншій особі (кредитору, потерпілому тощо), повинен повернути їх не у спочатку обумовленій сумі, а із зазначеним приростом, якщо тільки інше прямо не встановлено законом або договором». Тому, на думку дослідника, проценти за користування чужими грошовими коштами «не $\epsilon$ ні неустойкою, ні збитками, оскільки не $\epsilon$ заходами відповідальності за правопорушення. Отже, відсотки «є платою за користування чужими грошовими коштами (такими, що підлягають передачі уповноваженим особам), бо в майновому обороті гроші теж $\epsilon$ товаром і використовуються на відплатних засадах (якщо безоплатний характер їх використання не встановлено законом або договором)» [4, с. 456].
3 іншого боку, у таких договорах, як договір купівлі-продажу та договір ренти, вимога кредитора про сплату боржником процентів за користування чужими коштами $\epsilon$ правовим наслідком невиконання чи неналежного виконання договірних зобов'язань та спрямована на захист суб'єктивних прав у договірних правовідносинах. В.В. Вітрянський, досліджуючи природу сплати процентів за користування чужими грошовими коштами, зазначає, що справа тут не тільки в актуальності відповідних норм в умовах кризи неплатежів, коли, з одного боку, не оплачуються поставлені товари, виконані роботи або надані послуги, а з іншого боку, недобросовісні продавці, підрядники й інші контрагенти в договорах, отримавши як передоплату грошові суми покупців і замовників, користуються ними у своїх інтересах, не виконують своїх зобов'язань за договором. Стягнення процентів за грошовими зобов'язаннями має на меті захист прав і законних інтересів учасників майнового обороту, які сумлінно виконують свої зобов'язання, від незаконних дій їхніх контрагентів і компенсації завданої їм шкоди [5].

Погоджуючись із вченим, загалом зазначимо, що, якщо розглядати сплату процентів за користування чужими грошовими коштами з позицій правових підстав ії застосування, закріплених у ст. ст. 692-694, а також ст. 736 ЦК України, цілком очевидним $€$ висновок про те, що ними $\epsilon$ саме порушення (прострочення виконання) зобов'язання за договором, що порушує суб'єктивні майнові права кредитора і дозволяє йому застосувати адекватні такому порушенню правові прийоми, спрямовані на захист своїх прав. У цьому й проявляється компенсаційно-захисна функція сплати процентів за користування чужими грошовими коштами.

У правовідносинах із договорів позики, кредиту, банківського вкладу та банківського рахунку сплата процентів за користування чужими грошовими коштами $€$ звичайною умовою, яка зазначена в усіх зобов'язаннях, що виникають із вказаних договірних конструкцій, і не пов'язана з їх порушенням. У цьому контексті інтерес викликає думка Л.О. Єсипової, яка, коментуючи положення ст. 536 ЦК України, 
зазначає, що редакція ст. 536 ЦК України $€$ цікавою з погляду правової природи процентів, які розглядаються як борг, а не відповідальність. Та обставина, що відсотки за цією статтею $є$ боргом, виражається, зокрема, у відсутності зв'язку між можливістю їх стягнення і наявністю підстав юридичної відповідальності, а також у неприпустимості їх зменшення на вимогу боржника [6, с. 388].

Натомість ч. 2 ст. 625 ЦК України закріплює правило, згідно з яким боржник, який прострочив виконання грошового зобов'язання, на вимогу кредитора зобов'язаний сплатити суму боргу з урахуванням встановленого індексу інфляції за весь час прострочення, а також три проценти річних від простроченої суми, якщо інший розмір процентів не встановлений договором або законом. Очевидно, що вказана норма також присвячена правовому регулюванню відносин із користування чужими грошовими коштами, адже невиконання грошового зобов'язання завжди зумовлене непереданням або несвоєчасним переданням боржником грошових коштів, що належать кредитору згідно з умовами договору. Водночас досліджуваний випадок можливості стягнення з боржника процентів безпосередньо пов'язаний із порушенням договірного зобов'язання, що $\epsilon$ підставою для застосування кредитором способів захисту своїх прав.

Конкретизацію правової природи сплати процентів за користування чужими грошовими коштами відображає ч. 6 ст. 231 Господарського кодексу (далі - ГК) України «Розмір штрафних санкцій», відповідно до якої штрафні санкції за порушення грошових зобов'язань встановлюються у відсотках, розмір яких визначається обліковою ставкою Національного банку України, за весь час користування чужими коштами, якщо інший розмір відсотків не передбачено законом або договором. Отже, господарське законодавство відносить сплату процентів за користування чужими грошовими коштами до штрафних санкцій, які згідно зі ст. 20 ГК України віднесені до способів захисту суб'єктивних прав учасників господарських правовідносин.

Підсумовуючи вищезазначене, робимо висновок про таке. На нашу думку, у най- більш загальних рисах можливість стягнення процентів за користування чужими грошовими коштами закріплена у ст. 536 ЦК України, яка включає у свій зміст і зобов'язання щодо їх сплати за належного виконання учасниками договірних правовідносин взятих на себе зобов'язань (договір позики, кредитний договір, договір банківського вкладу, договір банківського рахунка), і зобов'язання, які виникають у божників унаслідок невиконання чи неналежного виконання своїх обов'язків та відповідно порушення договірних прав їхніх контрагентів (договір купівлі-продажу, договір ренти). У першому випадку сплата процентів за користування чужими грошовими коштами за своєю сутністю є грошовим зобов'язанням, має характер звичайної договірної умови і наявна в кожному правовідношенні, опосередковуваному вказаними договірними конструкціями. Натомість у другому випадку сплата процентів за користування чужими грошовими коштами $\epsilon$ забезпеченим законом правовим прийомом, застосовуваним кредитором унаслідок порушення (прострочення) боржником договірного грошового зобов'язання в рамках реалізації захисту своїх порушених суб'єктивних прав, що випливають із договірних правовідносин, та відповідно виконує компенсаційно-захисну функцію. Саме в цьому, на нашу думку, знаходить свій прояв подвійна правова природа закріпленої у ст. 536 ЦК України категорії сплати процентів за користування чужими грошовими коштами.

Вказаний висновок підтверджується й матеріалами судової практики, зокрема справою № 925/419/21, яка розглядалася Господарським судом Черкаської області. Так, Спільне українсько-естонське підприємство у формі ТОВ «Оптіма-Фарм, Лтд» звернулося до суду з позовом до ТОВ «Чорнобаївська центральна районна аптека № 35», у якому просило суд стягнути з відповідача заборгованість за договором поставки № 68607 від 14 травня 2019 р. у розмірі 214045,98 грн, яка складається із 178371,65 грн основної суми заборгованості та 35 674,33 грн відсотків за користування чужими грошовими коштами. 14 травня 2019 р. між позивачем (постачальником) та відповідачем 
(покупцем) було укладено договір поставки № 68607 (далі - договір). За умовами цього договору постачальник зобов'язався поставити та передати у власність покупця лікарські засоби та вироби медичного призначення (далі товар), а покупець зобов'язується прийняти товар, асортимент та ціна якого зазначені у видаткових накладних, які $\epsilon$ його невід'ємною частиною (п. 1.1 договору). За умови прострочення покупцем строків оплати за товар за цим договором він повинен сплатити постачальнику суму боргу з урахуванням встановленого індексу інфляції за весь час прострочення та проценти за користування чужими грошовими коштами в розмірі двадцяти відсотків від простроченої суми оплати (п. 10.4 договору). Свій обов'язок щодо оплати придбаного товару відповідач виконав частково, залишок заборгованості за отриманий товар станом на день розгляду справи становить 166 871,65 грн. Оскільки відповідач у визначений у договорі строк не розрахувався, наведене стало підставою для звернення позивача до суду для захисту порушеного права та примусового стягнення з боржника заборгованості та нарахованих позивачем відсотків за користування чужими грошовими коштами. Проаналізувавши умови договору, суд дійшов висновку, що в разі прострочення покупцем сплати вартості товару сторонами погоджено право продавця на нарахування $20 \%$ річних як процентів за користування чужими грошовими коштами на суму заборгованості покупця за весь період користування грошовими коштами, які належать до сплати постачальнику, починаючи з дати одержання товару. Тобто сторонами застосовано право, яке передбачене ч. 3 ст. 692 ЦК України. Вказана норма закону $є$ спеціальною у правовідносинах купівлі-продажу (поставки) та, по суті, конкретизує положення, які викладені у ст. 536 ЦК України. Визнавши позовні вимоги обґрунтованими, суд ухвалив рішення позов задовольнити та стягнути з відповідача суму боргу та проценти за користування чужими грошовими коштами [7]. На нашу думку, зазначена судова справа ще раз підтверджує необхідність та доцільність сприйняття сплати процентів за користування чужими грошовими коштами власне як спеціального способу захисту суб'єктивних прав у договірних зобов'язаннях, який $є$ належним та ефективним у разі порушення (прострочення) боржником грошового зобов'язання.

\section{ЛITEPATУPA:}

1. Кот О.О. До питання про способи захисту договірних прав. Юридична Україна. 2016. № № 9-10. C. 58-65. URL: http://nbuv.gov.ua/UJRN/urykr_2016_9-10_10 (дата звернення: 09.09.2021).

2. Білокан I.В. Зобов'язально-правові та спеціальні засоби захисту права власності в підприємницькій діяльності : автореф. дис. ... канд. юрид. наук: 12.00.03. Київ, 2008. 20 с.

3. Білокан I.В. Зобов'язально-правові засоби захисту прав сторін у договірних відносинах. URL: http://www.stattionline.org.ua/pravo /76/12179-zobov-yazalno-pravovi-zasobizaxistu-prav-storin-u-dogovirnix-vidnosinax.html (дата звернення: 09.09.2021).

4. Гражданское право : учебник : в 2-х т. / отв. ред. Е.А. Суханов 2-е изд., перераб. и доп. Москва : БЕК, 2000. Т. І. С. 456.

5. Договорное право. 2-е изд., испр. Москва : Статут, 1999. Кн. 1 : Общие положения. 848 c. URL: https://uristinfo.net/dogovornoe-pravo/93-dogovornoe-pravo-obschie-polozhenijakn-1/2185-3-zaschita-kreditora-v-dogovornom-objazatelstve.html (дата звернення: 12.09.2021).

6. Цивільний кодекс України : Коментар / за заг. ред. Є.О. Харитонова, О.М. Калітенко. Харків : ТОВ «Одіссей», 2003. С. 388.

7. Рішення Господарського суду Черкаської області від 1 червня 2021 р. у справі № 925/419/21. URL: https://reyestr.court.gov.ua/Review /98042360 (дата звернення: 18.09.2021). 